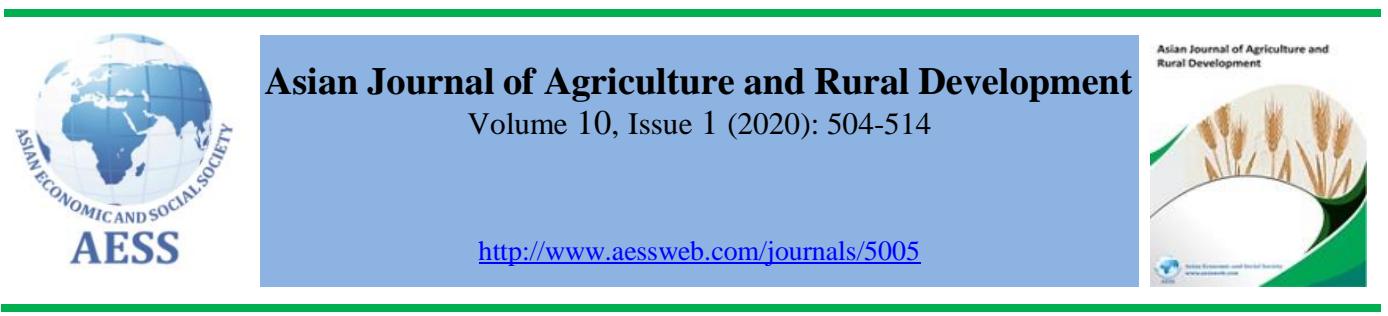

\title{
ADVERSE EFFECTS OF CLIMATE CHANGE ON AGRICULTURE: AN EVALUATION OF FRUIT AND HONEY BEE FARMING
}

\author{
Hülya Sayğı Vocational School of Yumurtalık, Cukurova University, \\ Turkey \\ $\triangle$ husaygi@gmail.com
}

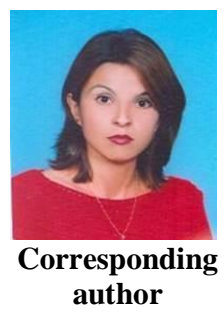
\begin{abstract}
2020
\section{Keywords:}

Climate change, Global warming, Fruit production, Beekeeping
\end{abstract}

ARTICLE HISTORY:

Received: 19-Mar-2020

Accepted: 20-May-2020

Online Available: $30-J u n-$

ABSTRACT
Agriculture is one of our most basic activities that are done depending
on nature with scarce resources and directly affects our life and nature.
This activity, which we have met our needs from past to present, is
under threat due to climate change and will not be able to produce the
expected benefits in the future if measures are not taken immediately.
In this study, the negative effects of climate change on agriculture are
discussed under the sub-heading fruit production and bees that have an
active role in fruit production. In this study, secondary data sources
related to the subject (academic publications, explanations by
authorized institutions and organizations, and future projections
created by them) were used. The findings obtained in the study
reached that if the necessary steps regarding climate change are not
taken immediately, the presence of bees will decrease. As a result, fruit
production will be negatively affected because pollination, which is
the main factor in fruit production.

\section{Contribution/ Originality}

Climate change will adversely affect agriculture, especially in terms of fruit production and bees. The study draws attention to agriculture and the importance of fruit growing as an agricultural production activity and the possible negative effects of climate change on them, emphasizing the importance of bees performing the pollination (in terms of biodiversity conservation), which is the main process of fruit production, and shedding light on subsequent studies.

DOI: 10.18488/journal.1005/2020.10.1/1005.1.504.514

ISSN (P): 2304-1455/ISSN (E):2224-4433

How to cite: Hülya Sayğ 1 (2020). Adverse effects of climate change on agriculture: An evaluation of fruit and honey bee farming. Asian Journal of Agriculture and Rural Development, 10(1), 504514.

(C) 2020 Asian Economic and Social Society. All rights reserved. 


\section{INTRODUCTION}

As a result of gases released into the atmosphere by people increasing the effect of natural greenhouse gases, the rise in the average temperature on the earth's surface, and the resulting climate changes are expressed as global warming (Dellal et al., 2011). Climate change is the result of changes in the composition of gaseous components in the atmosphere, as well as temperature increase and its associated effects. The temperature of the World is regularly increasing. It has raised around $0.7^{\circ} \mathrm{C}-0.8^{\circ} \mathrm{C}$ in the last 100 years (Saglam et al., 2008), will increase between $0.9^{\circ} \mathrm{C}$ - $3.5^{\circ} \mathrm{C}$ until 2100 (Chakraborty et al., 2000). If the necessary precautions are not taken, it is estimated that the temperature will continue to increase (Saglam et al., 2008). These estimates support the data in Figure 1. The figure shows the temperature change from 1860 to 2019, prepared by institutions that analyze global temperature change (Berkeley Earth, NASA's GISTEMP, NOAA's GlobalTemp, the U.K.'s HadCRUT, Cowtan \& Way, and ECMWF's). When Figure 1 is analyzed, it is seen that forecasts of climate change can be realized.

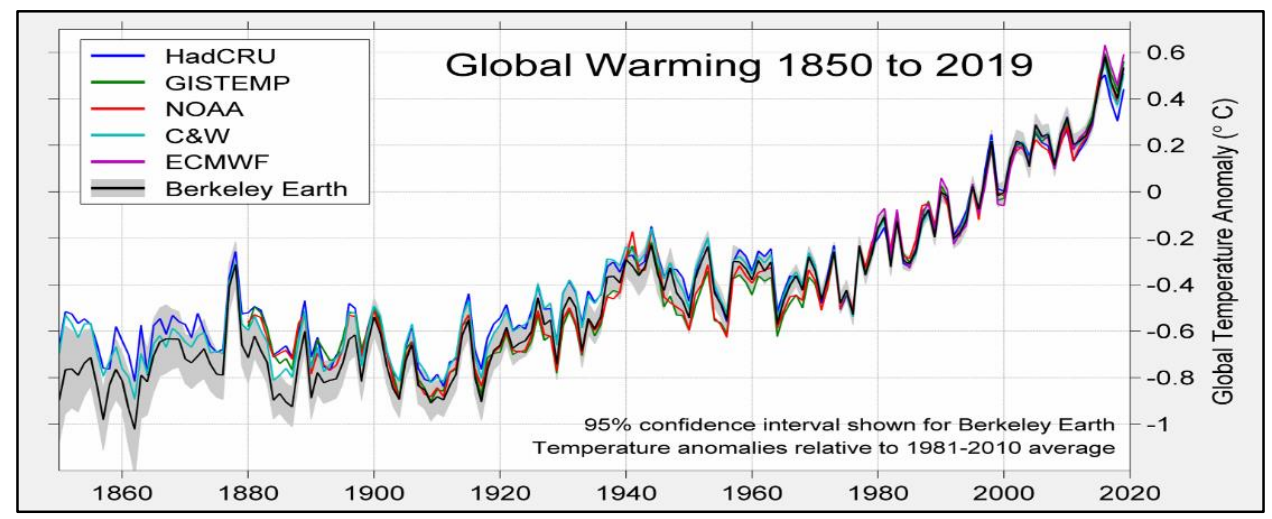

Figure 1: Pattern of global warming from 1850 to 2019

Source: Barkeky Earth, 2020

Turkey can be seen as one of the countries most affected by climate change as a result of the country's complex climate structure (Özturk, 2002; Kapluhan, 2013). The severity and strength of the climate change signals formed worldwide by regional climate change models. Hence, Mediterranean and Central Anatolia regions will get affected by climate change in different ways and to the different extent due to the country being surrounded by seas on three sides, to it having variable topography, and to its orographic features (Giorgi ve Lionello, 2008; Kapluhan, 2013).

It is estimated that rainfall in some important areas which benefit from rainwater such as Kansas and Oklahoma will lessen (Tubiello et al., 2002). A set of agroclimatic indices representing Canadian climatic conditions for field crop production is analyzed for long-term trends from 18952007. Results indicate that in-season plants might become more vulnerable against cold- stress and wounds as a result of a significant lengthening of the growing season due to a significantly earlier start and a substantially later end of the growing season (Qian et al., 2010). According to the results of the public agricultural institutions' research survey conducted in 47 provinces in Japan to determine the effects of the recent warming trends in agricultural production in 2003 and 2005, it was observed that the current warming trends significantly affected almost all plant and animal species. (Sugiura et al., 2012). It has been stated that loss, which may occur due to plant diseases because of climate change, will be influenced by three factors, such as disease management strategies, disease effectiveness, and geographic distribution of plant diseases (Chakraborty et al., 2000). 
Due to its nature-dependent structure, agricultural activities are one of the sectors most affected by climate change, and the reduction of greenhouse gas emissions that cause climate change also affects agricultural production activities of countries. Fruit production is the agricultural activity in which the effects of global warming and climate change are most intense, and perennial plants are more affected by sudden temperature changes. One of the conditions frequently seen in recent years is the extreme weather conditions during winter rest, flowering, and bud formation in fruit trees. While this situation directly affects fruit production and quality, it also has negative effects on bees involved in pollination. Changes in climate trigger the formation of weak colonies in honey bees, causing the spread of diseases, lost bees, and deaths. After this part of the study, the studies on fruit growing and beekeeping activities will be synthesized, and the importance of the subject will be explained.

\section{EFFECTS OF CLIMATE CHANGE ON FRUIT PRODUCTION ACTIVITIES}

As fruit production is a multi-annual agricultural activity, it is more affected by global climate changes. To obtain high-quality products with balanced flowering and fruit set in the cultivation of fruit species, the chilling requirement, of which periods differ for varying fruit species, is needed. With the data of 4293 weather stations in the World, the amount of chilling exceeding $90 \%$ of all years was estimated using a dynamic model for safe winter chilling. It has been reported that in the warm and temperate regions, severe and potentially production threatening drops, and in cold areas, a rise in temperature can be observed (Luedeling et al., 2011). However, if global warming is analyzed in general, it has the potential to increase the air temperature in the winter period. These predicted temperature changes would have adverse effects in the regions where most fruit species, grapevine, and hard-shelled fruit production are common (Webb et al., 2007; Campoy et al., 2011; Luedeling et al., 2011; Pope et al., 2014).

It is stated that in the Margaret River region of Australia, bud burst will be delayed as a result of not meeting the chilling requirement in grape production due to the temperature increase (Webb et al., 2007). It has been reported that to face the possible effects of climate change the efforts should be made to produce varieties of trees with lower chilling needs, to develop tools to deal with insufficient winter coldness and to understand better the reaction of products to temperatures (Luedeling et al., 2011).

In January 2020, the surface temperature of the oceans and lands in the World increased from the average temperature of the twentieth century to $1.14^{\circ} \mathrm{C}\left(2.05^{\circ} \mathrm{F}\right)$, reaching the highest temperature recorded in 141 years. This value has been $0.02^{\circ} \mathrm{C}\left(0.04^{\circ} \mathrm{F}\right)$ higher than the January average temperature since 2016. January has been recorded as the hottest month four times since 2016, while it has been recorded as the hottest month ten times since 2002. In January, the surface temperature of the oceans and lands in the World increased by $1{ }^{\circ} \mathrm{C}\left(1.8^{\circ} \mathrm{F}\right)$ in 2016 and 2020 , above the average temperatures (NCDC Noaa, 2020) (Figure 2).

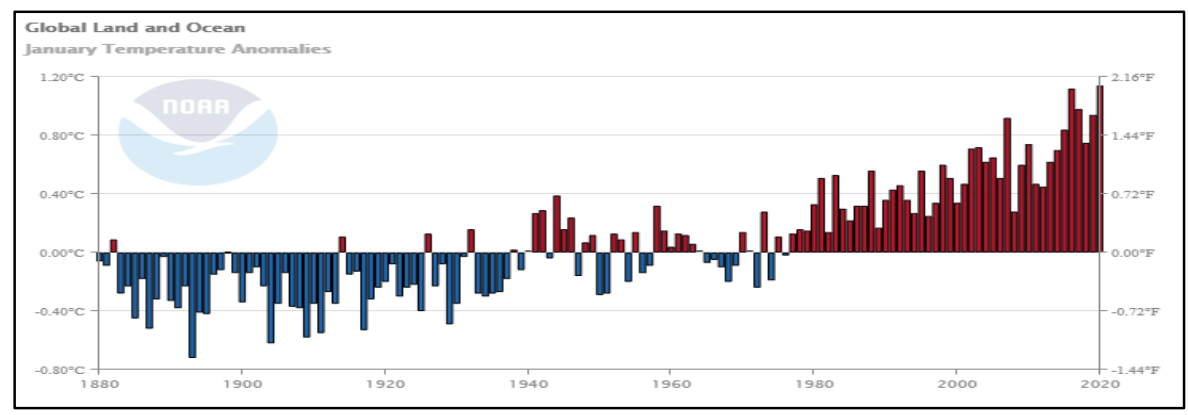

Figure 2: Monthy surface temperature

Source: NCDC, 2020 
A significant temperature increase is predicted, especially in summer (Giorgi and Lionello, 2008). The temperature rise in the winter will cause some problems in providing the winter chilling requirement and bud awakening in the fruit species, while the temperature rise in the summer months will cause some problems such as twin fruit formation (Beppu and Kataoka, 1999; Engin and Unal, 2004; Imrak and Kuden, 2012). For instance, when researches on twin fruit formation that reduces fruit quality and market value in cherry cultivation are observed; it was determined that in regions with hot climates, while the normal single female organ was formed at $25^{\circ} \mathrm{C}$ in the period of flower bud differentiation of the previous year, the rate of double female organs increased at $30^{\circ} \mathrm{C}$ (Imrak and Kuden, 2012), and it has gone up to $80 \%$ at $35^{\circ} \mathrm{C}$ and above (Beppu and Kataoka, 1999; Engin and Unal, 2004).

The effects of global warming on vine phenology in Australia are modeled in 6 regions for 2 varieties with high commercial importance. It has been determined that the time of bud burst in Cabernet Sauvignon variety in the Coonawarra region will be 4-6 days in 2030 and 6-11 days earlier in 2050. It is thought that the harvest time will be reduced to early in all regions studied, and the harvest maybe 45 days earlier in the Coonawarra region until 2050 according to the highest temperature scenario (Webb et al., 2007).

Extreme changes in air temperatures also have a negative effect on the flowering periods of fruit species (Omoto and Aono, 1990; Guédon and Legave, 2008; Legave et al., 2008). It is stated that changes occurring in flowering phenology will affect pollination and fruit set and cause problems in production by increasing the risk of catching late spring frosts (Zavalloni et al., 2004). In a study on the effects of global climate change on apple cultivation in the Hesse region, it has been reported that between 2031 and 2060, the trees will start blooming 6-8 days early and there will be a significant increase in the risk of late spring frost during the flowering period (Braun and Müller, 2012).

In most temperate fruit-producing regions, the effects of climate change on safe winter coldness differ quantitatively between global climate models and greenhouse gas emissions scenarios (Luedeling et al., 2011). Cold damage is the main problem that restricts fruit production in the Okanagan Valley (USA). When the historical records between the years 1916 \& 2006 are analyzed, it is seen that severe lethal cold damage occurred 16 times. Although this period is the 4-month period in which the products are most exposed to cold damage, the periods involving risk for each species differ. If climate changes continue, a decrease is expected in the production of grapes, apples, and cherries in this region. In contrast, it is expected that there will be an expansion in the fields of pear, apricot, and peach production (Quamme et al., 2010).

The low-temperature tolerance seen in winter is the result of genotype interaction with the environment, affecting plant development and metabolic activity at low temperatures and freezing conditions. In addition, subzero temperature tolerance mechanisms vary with tissue type, age, and season and climate conditions (Fennell, 2014).

Since the temperature change directly affects photosynthesis, the increase in temperatures can have an important effect on the post-harvest quality of the products by changing important quality parameters such as sugars, organic acids, synthesis of antioxidant compounds and hardness. The level of rising ozone causes different types of visual damage and physiological disorders, as well as changes in dry matter, reducing sugars, citric and malic acid, and other important quality parameters (Moretti et al., 2010). Possible effects of climate change on anthocyanin and titratable acidity levels of grape varieties grown in Western Australia were estimated for the years 2030, 2050 and 2070, and it was stated that it would be negatively affected by global warming under current management practices (Barnuud et al., 2014). 
As a result of the extreme temperature increase occurring in the summer period, the high temperature at the time of harvest affects the quality of the grapes negatively due to the early harvest time in grapes (Webb et al., 2007). The increase in a harvest period and temperature in wine-growing causes the increase in sugar concentration and alcohol level, low acidity, and modification of flavor compounds depending on the species. The negative changes in wine phenology and grape composition, also affects the wine microbiology, chemistry, and sensory properties (De Orduna, 2010).

Considering the data of the Central Hungarian, the grape-growing regions, extreme weather events such as floods, frost, drought, heat waves that have started to occur more frequently have been observed under global climate change. It has been stated that changing climatic conditions in the Carpathian basin can affect the quality and quantity and cause negative economic results and create stress effects (Szenteleki et al., 2012).

A study evaluates the effects of climate change and to investigate the relationship between environmental suitability in the cultivation of "Pequi" (Caryocar Brasiliense) fruit tree in Brazil, it concludes that there will be a drop in production and absolute measures must be taken until 2050 (Nabout et al., 2011). In Turkey, although it is a species resistant to dry conditions, olive (Olea Europa) has been reported to be one of the agricultural products that will be most affected by global climate change. Therefore urgent measures should be taken in olive cultivation (Varol and Ayaz, 2012). It has been stated that it should be considered in some way that the production values of almond (Prunus dulcis), pistachio (Pistacia vera), and walnut (Juglans regia) grown in California have been compared with 50-year meteorological records. As a result of the hot winters caused by the effects of climate change in fruit species, the processes after the bud burst period are more dangerous (Pope et al., 2014).

In the U.K., studies are carried out to determine energy efficiency within the food marketing system. It has been stated that because importation of fruit and vegetables by air causes a large amount of greenhouse gas production, this method should be avoided. As a solution, local production should increase. Compared to products supplied locally, it has been determined that products imported by air produce $9.66 \mathrm{~kg}$ more CO2 emissions (Michalský and Hooda, 2015).

It has been reported that future research should be aimed at minimizing seasonal changes, aiming at sustainable and profitable production of high-quality fruit growing for private uses in the face of water and labor shortages, consumer preferences, and global competition (Keller, 2010). Following this section, possible negative effects of climate change on pollinating bees (wild bees and cultivated bees), which are an essential step in fruit growing, and the results of these effects will be explained.

\section{THE EFFECT OF CLIMATE CHANGE ON BEES REALIZING POLLINATION IN FRUIT PRODUCTION}

Over $75 \%$ of the World's crop production is due to pollination by bees, butterflies, birds, moths, insects, and even bats. This rate is even higher in fruit production because fruit production depends on pollination. Pollination is the most crucial function in fruit production, and bees are in the foreground among these (Hafi et al., 2012). Figure 3 shows the effect of honey bees on pollination in vegetative production. Similar data for fruits is presented in Figure 4.

Pollination is an essential element in the reproduction of flowering plants, and it is defined as the process of carrying pollen from the same organs of a flower of the same type or from the male organs (stamen) to the female organ (pistil) of different kinds of flowers (Free and Williams, 1977). Pollination is a prerequisite for the formation of seeds and fruits in flowering plants. The most 
important factor in low yield is fertilization weakness, and the critical factor for productivity is pollination (McGregor, 1976).

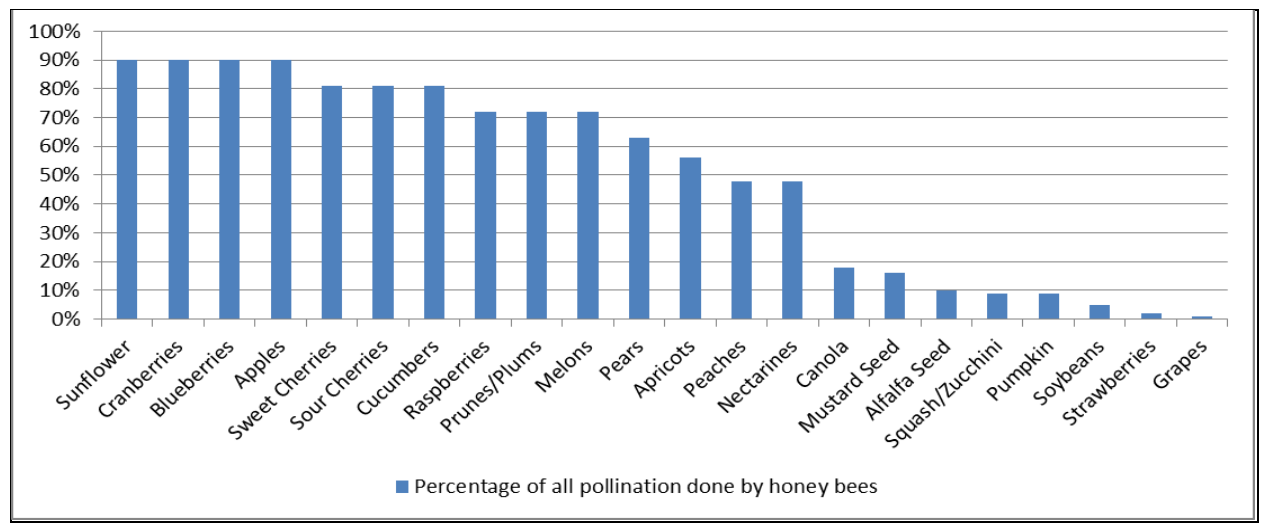

Figure 3: Percentage of all pollination done by honey bees

Source: https://www.agr.gc.ca/eng/agriculture-and-agri-food-canada/?id=1395690825741

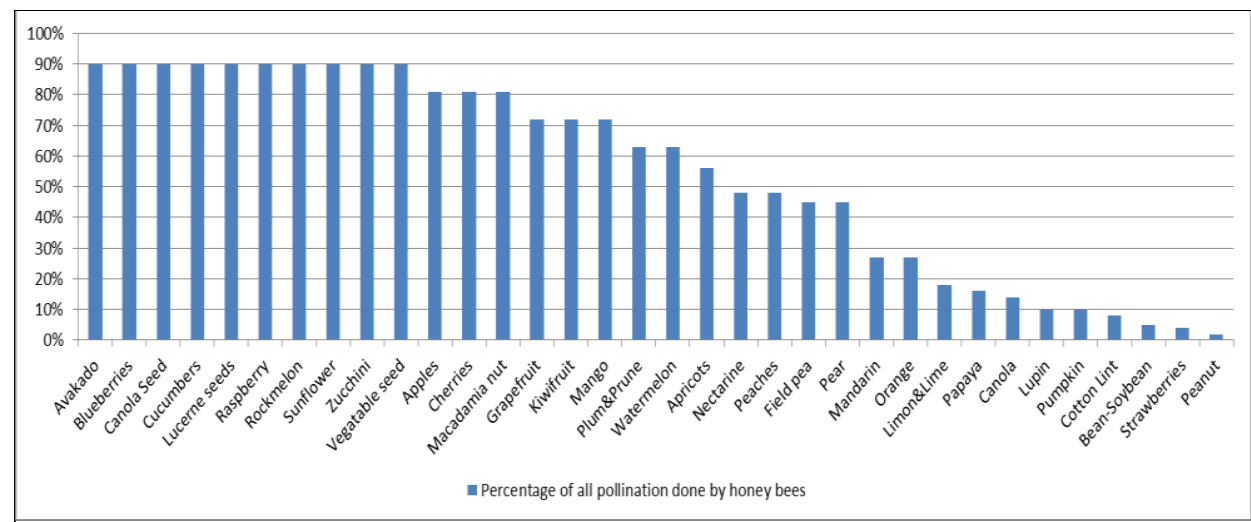

Figure 4: Percentage of all pollination done by honey bees

Source: ABARES, 2019

Janick et al. (1996) reported that suitable pollinator varieties should be kept in the garden, and necessary precautions should be taken to obtain sufficient and high-quality products from cherry trees. Pollination in crop production; It is realized by wind (anemopoli), insects (entomofoli), especially honey bees.

Changes in the global climate will likely affect the behavior and lifestyle of many beings, including insects. For insects, the increase in temperature and humidity means an increase in growth rate, displacement rate, and reproductive capacity. These changes can also affect ecological processes occurring in nature. Changes in climate will also change the character of the environment in which living things exist, and these changes will indirectly affect the behavior of insect populations living in that ecological environment.

It is thought that the changes in the climate factors will cause some important differences in the physiology and geographical spread limits of the insects since they are cold-blooded. In particular, changes in temperature and humidity affect the function of insect metabolism, reproductive capacity, nutritional habits, and in accordance, its spread (Akbulut, 2000). 
Global warming can cause living species living in a region to leave the region they live in, as well as allowing new invasive species that are not specific to the region to settle. One of the most remarkable effects of global warming is that some species have disappeared from the World (Dogan et al., 2010). In a study, nine species of bees showed adverse effects on body weight and development in some species as a result of the increase in winter temperature $\left(1.5-9.5^{\circ} \mathrm{C}\right)$. It was stated that an increase in weight loss, energy consumption and that the life cycle of some species ended in spring. Wild bees, which are the forefront among bee species due to their adaptation capabilities, become important in climate change (Fründ et al., 2013).

Global warming leads to a linear increase at the beginning of flowering and the appearance of pollinators. Although differences in the phenological responses to climate change between species are expected, these reactions occur in the same proportion between the plants and those pollinating them. It has been determined from the studies that the pollination communication service structure is strong against the concern caused by global warming. It has been stated that phenology, geographical distribution and local abundance of plants and pollinators are affected by climate change. In contrast, plant flowering and pollination activity time are strongly influenced by temperature (Hegland et al., 2009).

Climate change affects honeybee behavior and physiology. Decreasing flower quality in the environment may decrease colony development and, thus, colony honey production capacity (Le Conte and Navajas, 2008). The sudden climate changes and the negative effects of global warming make the future of the plants and the lives of the bees difficult. Low temperature and high humidity; cause the bee activity to decrease, and the release of pollen from the fruit flower slows down (Braun and Müller, 2012).

Global warming and climate change affect phenology, local wealth, and large-scale distribution of plants and pollinators (Rader et al., 2013; Türkoğlu et al., 2016). In addition, climate changes and irregularities in colony development weaken honeybee colonies, diseases are becoming widespread, they cannot return to the honey bee hive that has gone out of the hive to continue their field activities, and deaths occur (Şahin et al., 2015).

If climate change affects pollinator-dependent herbal production, this will have important implications for global food security, because insect pollination contributes to the production of $75 \%$ of leading global food products. Whether global warming has indirect effects on plant pollination services has been investigated. It was stated in the study that there would be a $14.5 \%$ reduction in pollination managed by honey bees, and an increase in pollination provided by domestic wild species, as a result of the warming of $2,4 \mathrm{o} \mathrm{C}$ and $6,4^{\circ} \mathrm{C}$, which will occur until 2099 on watermelon pollination. Researchers suggested that to minimize the effects of climate change, the domestic biodiversity should be conserved since the plant pollination will fall faster without domestic pollinators (Rader et al., 2013).

The adaptation of honey bees to their environment is expressed as the annual development of the colony. Food sources balance and host-parasite balance and environmental changes interact with each other. In the research, 597 colonies from 5 Apis mellifera subspecies (carnica, ligustica, macedonica, mellifera, siciliana) belong to 16 different genetic origins in 11 European countries from Central Europe and the Balkans to Scandinavia, are grouped in 6 environmental clusters, and development models were analyzed over two years. While the juvenile population tended to be smaller in the North, colonies placed in Southern Europe tended to have a lower adult bee population than colonies placed in cold conditions. In other words, while bees in hot climates show shorter lifespan, there is a shorter breeding period in the North. It has been stated that genotype and environment significantly affect colony development and is especially important in terms of the adult bee population and wintering ability (Hatjina et al., 2014). 
The single living Osmia lignaria bee needs a certain period of cold to complete the pause period (diapause). To examine the effect of long summers on Osmia lignaria populations, the researchers deal individuals to 3 simulated treatments (early- mid-late winter); respiration rates, metabolic consumption, weight loss, body fat loss, lipid levels, and winter death data were taken. Early winter practice disrupted the development of the pause period but had no negative effect on physical development. On the contrary, late winter bees cause more energy consumption (1.5 times), more weight (1.4 times), and more lipid loss (2 times), while a $19 \%$ increase in mortality compared to mid-winter. Therefore, in the global warming scenario, it is stated that, despite the delay in winter, the long summer pause period diapotic phenotypes that replace the short summer pause period can replace the phenotypes with a short summer pause period (Sgolastra et al., 2011).

\section{CONCLUSION}

Global warming and climate change associated with it is a scientific reality accepted by all circles. Although climate change has some positive effects on nature, it is claimed that the negative effects will be more. Agriculture is carried out depending on nature and climatic conditions. For this reason, it is a fact that agriculture will be affected by climate change at a higher rate. The subject of our study is to examine the effects of these claims on agriculture in terms of fruit production and bees (performing pollination, which is a fundamental process in fruit production). Accordingly, due to the sudden change in temperature, it was observed that the climate demands of the plants in the fruit production could not be achieved, and abnormal conditions occurred in the reactions of the plants against this situation, and this caused a decrease in the yield and product quality. It is concluded that the bees that perform pollination for fruit production are also affected by the sudden climate change. The climate, which is one of the stress factors in beekeeping, directly affects the nutrients that the bee needs, and sudden climate changes have consequences leading to a decrease in resistance in weak colonies, an increase of disease and harmful activity, and eventually extinction of the colony. Damage to the existence of bee, which is the basic pollinator in plant production, will result in a significant decrease in fruit production.

As a result, it is expected that fruit production and bee existence will be adversely affected by climate change, and this effect will increase over time. The study evaluates the possible negative effects of climate change on agriculture in terms of fruit production and bees, which is involved in fruit production, to contribute to the literature in this field and to encourage studies in this field.

Funding: This study did not receive any specific financial support.

Competing Interests: The author declares that s/he has no conflict of interests.

Contributors/Acknowledgement: All the designing and estimation of current research done by sole author.

Views and opinions expressed in this study are the views and opinions of the authors, Asian Journal of Agriculture and Rural Development shall not be responsible or answerable for any loss, damage or liability, etc. caused in relation to/arising out of the use of the content.

\section{References}

Akbulut, S. (2000). Possible effects of global warming on insect populations. Ecology, 9(36), 2527.

Barnuud, N. N., Zerihun, A., Mpelasoka, F., Gibberd, M., \& Bates, B. (2014). Responses of grape berry anthocyanin and titratable acidity to the projected climate change across the Western Australian wine regions. International Journal of Biometeorology, 58(6), 1279-1293.

Beppu, K., \& Kataoka, I. (1999). High temperature rather than drought stress is responsible for the occurance of double pistil in 'satohishiki' sweet cherry. Scientia Hort. 81, 125-134. doi.org/10.1016/s0304-4238(99)00007-2.

Braun, P., \& Müller, M. (2012). Effects of climate change on fruit production in the state of hesse. INKLIM Module II plus, Abstract of the final report. 
Campoy, J. A., Ruiz, D., \& Egea, J. (2011). Dormancy in temperate fruit trees in a global warming context: a review. Sci Hortic (Amsterdam) 130, 357-372. doi.org/10.1016/j.scienta.2011.07.011

Chakraborty, S., Tiedemann, A. V., \& Teng, P. S. (2000). Climate change: potential impact on plant diseases. Environmental Pollution, 108(3), 317-326.

De Orduna, R. M. (2010). Climate change associated effects on grape and wine quality and production. Food Research International, 43(7), 1844-1855. doi.org/10.1016/j.foodres.2010.05.001.

Dellal, İ., McCarl, B. A., \& Butt, T. (2011). The economic assessment of climate change on Turkish agriculture. Journal of Environmental Protection and Ecology, 12(1), 376-385.

Dogan, S., Ozcelik, S., Dolu, O., \& Erman, O. (2010). Global warming and biodiversity. Climate Change and Environment, 3, 63-88. doi.org/10.1016/j.foodres.2010.05.001.

Engin, H., \& Unal, A. (2004). Effects of water deficiency on double fruit formation in cherries. Ege University, Faculty of Agriculture Bulletin, 41(2), 19-28.

Fennell, A. (2014). Genomics and functional genomics of winter low-temperature tolerance in temperate fruit crops. Critical Reviews in Plant Sciences, 33(2-3), 125-140. doi.org/10.1080/07352689.2014.870410.

Free, J. B., \& Williams, I. H. (1977). The pollination of crops by bees. Apimondia Publishing House, Bucharest.

Fründ, J., Zieger, S. L., \& Tscharntke, T. (2013). Response diversity of wild bees to over wintering temperatures. Oecologia, 173(4), 1639-1648. doi.org/10.1007/s00442-013-2729-1

Giorgi, F., \& Lionello, P. (2008). Climate change projections for the Mediterranean region. Global and Planetary Change, 63(2), 90-104. doi.org/10.1016/j.gloplacha.2007.09.005

Guédon, Y., \& Legave, J. M. (2008). Analyzing the time-course variation of apple and pear tree dates of flowering stages in the global warming context. Ecological Modeling, 219(1), 189199.

Hafi, A., Millist, N., Morey, K., Caley, P., \& Buetre, B. (2012). A benefit-cost framework for responding to an incursion of Varroa destructor. Research by the Australian Bureau of Agricultural and Resource Economics and Sciences (ABARES).

Hatjina, F., Costa, C., Büchler, R., Uzunov, A., Drazic, M., Filipi, J., \& Kezic, N. (2014). Population dynamics of European honeybee genotypes under different environmental conditions. Journal of Apicultural Research, 53(2), 233-247.

Hegland, S. J., Nielsen, A., Lázaro, A., Bjerknes, A. L., \& Totland, Q. (2009). How does climate warming affect plant-pollinator interactions? Ecology Letters, 12(2), 184-195.

Imrak, B., \& Kuden, A. (2012). Researches on the solution of the problem of multiple female organ formation in subtropic climate conditions of some cherry varieties. Ç. $\ddot{U}$ Journal of Science and Engineering Sciences, 28(5), 62-71.

Janick. J., Cummins, N., Brown, S. K., \& Hemmat, M. (1996). Apples. (In: J. Janick and J N Moore) Fruit Breeding Vol. I. Tree and Tropical Fruits, Wiley, New York, 177.

Kapluhan, E. (2013). Effect of agricultural drought and drought in Turkey. Marmara Geography Magazine, 27, 487-510.

Keller, M. (2010). Managing grapevine into optimise fruit development in a challenging environment: a climate change primer for viticulturists. Australian Journal of Grape and Wine Research, 16(1), 56-69. doi.org/10.1111/j.1755-0238.2009.00077.x.

Le Conte, Y., \& Navajas, M. (2008). Climate change: impact on honeybee populations and diseases. Revue Scientifique et technique International Office of Epizootics, 27, 485-97.

Legave, J. M., Farrera, I., Almeras, T., \& Calleja, M. (2008). Selecting models of apple flowering time and understanding how global warming has had an impact on this Trait. Journal of $\begin{array}{llll}\text { Horticultural Science } & \text { 76-84. }\end{array}$ doi.org/10.1080/14620316.2008.11512350.

Luedeling, E., Girvetz, E. H., Semenov, M. A., \& Brown, P. H. (2011). Climate change affects winter chill for temperate fruit and nut trees. PLoSOne, 6(5), 201-255. doi.org/10.1371/journal.pone.0020155. 
Mc Gregor, S. E. (1976). Insect pollination of cultivated crop plants. Agr. Res. Serv. U.S. Dept. Agr. Washington D.C.

Michalský, M., \& Hooda, P. S. (2015). Greenhouse gas emissions of imported and locally produced fruit and vegetable commodities: a quantitative assessment. Environmental Science \& Policy, 48, 32-43. doi.org/10.1016/j.envsci.2014.12.018.

Moretti, C. L., Mattos, L. M., Calbo, A. G., \& Sargent, S. A. (2010). Climate changes and potential impacts on post harvest quality of fruit and vegetable crops: A Review. Food Research International, 43(7), 1824-1832. doi.org/10.1016/j.foodres.2009.10.013.

Nabout, J. C., Oliveira, G., Magalhães, M. R., Terribile, L C., \& de Almeida, F. S. (2011). Global climate change and the production of "pequi" fruits (Caryocar brasiliense) in the Brazilian. Cerrado. Natureza\& Conservação, 9(1), 55-60. doi.org/10.4322/natcon.2011.006.

NCDC Noaa (2020). Monthly climate change report. January 2020. Retrieved from https://www.ncdc.noaa.gov/sotc/global/202001

Omoto, Y., \& Aono, Y. (1990). Estimation of change in blooming dates of cherry flower by urban warming. Journal of Agricultural Meteorology, 46, 123-129. doi.org/10.2480/agrmet.46.123

Özturk, K. (2002). Potential impact of global climate change and Turkey. Journal of Gazi Education Faculty, 22(1), 47-65.

Pope, K. S., Dose, V., Da Silva, D., Brown, P. H., \& DeJong, T. M. (2014). Nut crop yield records show that budbreak-based chilling requirements may not reflect yield decline Chill Thresholds. International Journal of Biometeorology, 59(6), 707-715.

Qian, B., Zhang, X., Chen, K., Feng, Y., \& O'Brien, T. (2010). Observed long-term trends for agroclimatic conditions in Canada. Journal of Applied Meteorology and Climatolog, 49(4), 604-618.

Quamme, H. A., Cannon, A. J., Neilsen, D., Caprio, J. M., \& Taylor, W. G. (2010). The potential impact of climate change on the occurrence of winter freeze events in six fruit crops grown in the Okanagan valley. Canadian Journal of Plant Science, 90(1), 85-93.

Rader, R., Reilly, J., Bartomeus, I., \& Winfree, R. (2013). Native bees buffer the negative impact of climate warming on honeybee pollination of watermelon crops. Global Change Biology, 19(10), 3103-3110. doi.org/10.1111/gcb.12264.

Sağlam, N. E., Düzgüneş, E., \& Balık, İ. (2008). Global warming and climate change. Ege Universty Journal of Fisheries and Aquatic Sciences, 25, 89-94.

Sgolastra, F., Kemp, W. P., Buckner, J. S., Pitts-Singer, T. L., Maini, S., \& Bosch, J. (2011). The long summer: pre-wintering temperatures affect metabolic expenditure and winter survival in a solitary bee. Journal of Insect Physiology, 57(12), 1651-1659.

Sugiura, T., Sumida, H., Yokoyama, S., \& Ono, H. (2012). Overview of recent effects of global warming on agricultural production in Japan. JARQ, 46(1), 7-13.

Szenteleki, K., Ladányi, M., Gaál, M., Zanathy, G., \& Bisztray, G. (2012). Climatic risk factors of central Hungarian grape growing regions. Applied Ecology and Environmental Research. 10(1), 87-105. doi.org/10.15666/aeer/1001_087105.

Şahin, M., Topal, E., Özsoy, N., \& Altunoğlu, E. (2015). Effects of climate change on fruit growing and beekeeping activities. Anadolu Journal of Natural Sciences, 6(2), 147-154. doi.org/10.1016/b978-0-12-818732-6.00007-1.

Tubiello, F. N., Rosenzweig, C., Goldberg, R. A., Jagtap, S., \& Jones, J. W. (2002). Effects of climate change on U.S. crop production: simulation results using two different GCM Scenarios. Part I: Wheat, Potato, Maize, AndCitrus. Climate Research, 20, 259-270. doi.org/10.3354/cr020259.

Türkoğlu, N., Şensoy, S., \& Aydın, O. (2016). Effects of climate changes on phenological periods of apple, cherry and wheat in Turkey Türkiye'de iklim değişikliğinin elma, kiraz ve buğdayın fenolojik dönemlerine etkileri. Journal of Human Sciences, 13(1), 1036-1057. doi.org/10.14687/ijhs.v13i1.3464.

Varol, N., \& Ayaz, M. (2012). Global climate change and olives. Journal of Turkish Scientific Reviews, 5(1), 11-13. 
Webb, L. B., Whetton, P. H., \& Barlow, E. W. R. (2007). Modelled impact of future climate change on the phenology of wine grapes in Australia. Australian Journal of Grape and Wine Research, 13(3), 165-175. doi.org/10.1111/j.1755-0238.2007.tb00247.x.

Zavalloni, C., Andresen, J. A., Winkler, J. A., Flore, J. A., Black, J. R., \& Beedy, T. L. (2004). The pileus project: climatic impact son sour cherry production in the great lakes region in past and projected future time frames. VII International Symposium on Modelling in Fruit $\begin{array}{llll}\text { Research and } \quad \text { Orchard } & \text { 101-108. }\end{array}$ doi.org/10.17660/actahortic.2006.707.12. 